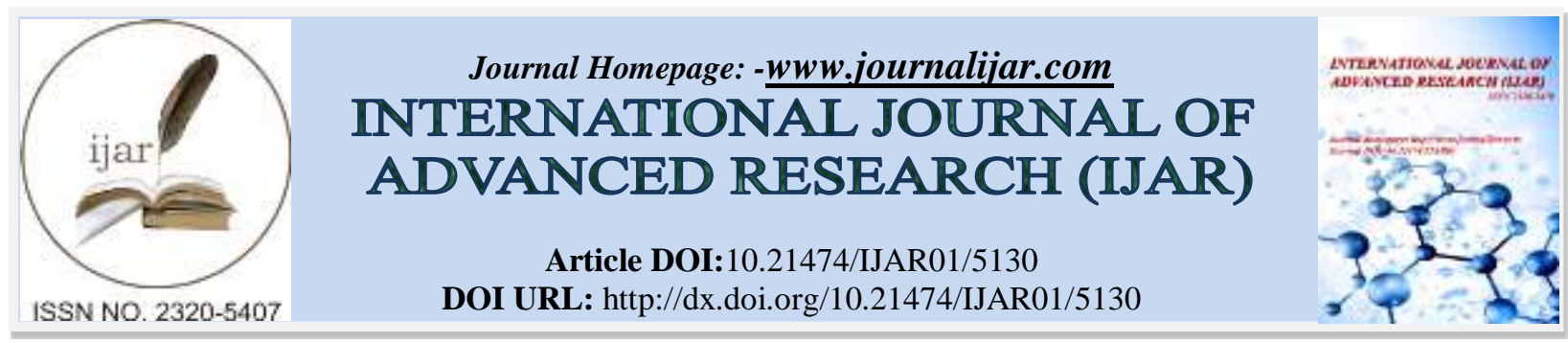

RESEARCH ARTICLE

\title{
LIFE INSURANCE: CHALLENGES AND OPPORTUNITIES IN RURAL INDIA.
}

\author{
Shoaib Alam Siddiqui and Dr. Stephen Das. \\ Joseph School of Business Studies, Sam Higginbottom University of Agriculture, Technology and Sciences, \\ Allahabad, India.
}

\section{Manuscript Info}

Manuscript History

Received: 10 June 2017

Final Accepted: 12 July 2017

Published: August 2017

Key words:-

Life insurance, India, Rural market,

Agents, Life insurers.

\begin{abstract}
Life insurance is very important for protecting human lives against accidents, causalities and other types of risks. Life insurance has been dominated by public sector (LIC) in India; however, with the liberalization of Indian economy, private sector entry in life insurance has got momentum. The public sector Insurance Company, i.e. LIC of India has emphasized on exploiting the potential of rural India as rural life insurance provides immense scope.But still its penetration is very low as compared to that in developed nations. This paper highlights emerging trends, patterns, and opportunities in Indian rural life insurance business. It also focuses on the role of private companies in life insurance in India.
\end{abstract}

Copy Right, IJAR, 2017,. All rights reserved.

\section{Introduction:-}

Life insurance was started in India in 1818 by the 'the Oriental Life Insurance Company' mainly by the Europeans from England to provide insurance to English widows. Foreign insurance companies had profound dominance in this market even after the establishment of the first Indian life insurance company, viz. Bombay Mutual Life Assurance Society in 1870. The main characteristic of such foreign companies was that they invested the proceeds of premium outside India so the Indian economy was not benefited thereby. This development, however, took place in the informal sector. The development of insurance business in the formal sector took momentum after the ratification of The Life Insurance Companies Act and The Provident Fund Act, in 1912. A more comprehensive legislation was, however, introduced in India under the Life Insurance Act of 1938 to ensure strict control over insurance business and an effective check on large-scale frauds that had evolved in this business during the 1930's. Life insurance business got a boost in independent India rightly from the eve of the planning era on account of its capacity to mobilize resources from the cross section of population, and to channelising them in productive activities. At the end of 1956, 154 Indian life insurance companies, 16 non-Indian companies and 75 provident fund societies were providing life insurance policies in the country. The Government of India, however, nationalized these business units, and amalgamated them under Life Insurance Corporation of India (LIC) in 1956 with a view to examine the structure of the insurance industry and to assess its strengths and weaknesses in terms of the objective of creating an efficient and viable insurance industry providing wide range of insurance services to the masses and an effective instrument for mobilisation of financial resources for the successful implementation of Five Year Plans. The year 1991, however, witnessed a paradigm shift in India's overall development strategy. The impacts of these new economic policies on LIC have been enormous. Keeping these in view, a Committee on Reforms in the insurance sector was set up in 1992 under the Chairmanship of R.N.Malhotra, which submitted its recommendations in 1994, was accepted in principle by the government and started implementing the recommendations since 
December 1999, thus heralding an era of liberalization in the country's insurance sector. The setting up of Insurance Regulatory and Development Authority (IRDA) and opening up of Insurance Business (life and general) to foreign capital up to 26 per cent were the initial steps in this direction. It is widely acknowledged that the opening up of the insurance sector has been aimed at ushering in greater efficiency in the insurance business by maximizing productivity and minimizing transaction cost.

\section{Opportunities and Potential of Rural Insurance:-}

Competition is believed to bring a wider choice of products at lower prices to the consumers, larger coverage of population, better customer services, superior information technology, higher returns to the policyholders, and so on. Though LIC grew amazingly in terms of business volume prior to 1999, it staggered in terms of geographical spread, especially in the countryside, as well as the number of lives coverage. Evidence indicates that its business had been confined to big cities, and within the cities, only to more affluent sections of the society. The rural sector shared only around 18 percent of its business in 2000. The Indian insurance market also fell short of the global standard. This paper is intended to analyse the importance of the life insurance opportunities and challenges in rural India. The census of 2011 shows that the rural sector in India comprises $68.84 \%$ of the population and generates about $26 \%$ of the GDP. Thus, the rural sector is important both politically and economically. Naturally, rural insurance has been emphasised since the nationalization of life insurance business in 1956. LIC of India followed a three-pronged strategy for life insurance. Firstly, it targeted the rural wealthy with regular individual policies. Secondly, it offered group policies to those who could not afford individual policies. Thirdly, for the very poor, it offered government-subsidized policies. It was noted in the section on regulation that, after five years of operation, every private sector life insurance company has to achieve a certain proportion of their business in the rural sector. It is a variable and rising proportion, with at least $15 \%$ of business in the rural sector after five years. It is $18 \%$ for Life Insurance Corporation of India.

\section{Impulse to go Rural:-}

There are many reasons that urge the companies to enter the uncharted territory of rural India. Some of the attractions are discussed below;

\section{Large Population:-}

The rural Indian population is large and its growth rate is also high. About $70 \%$ India's one billion plus population lives in around 627,000 villages in rural areas. This simply shows the great potentiality rural India has to bring the much needed volumes and help the Indian companies to bank upon the volume driven growth.

Figure 1:- Percentage distribution of households and income

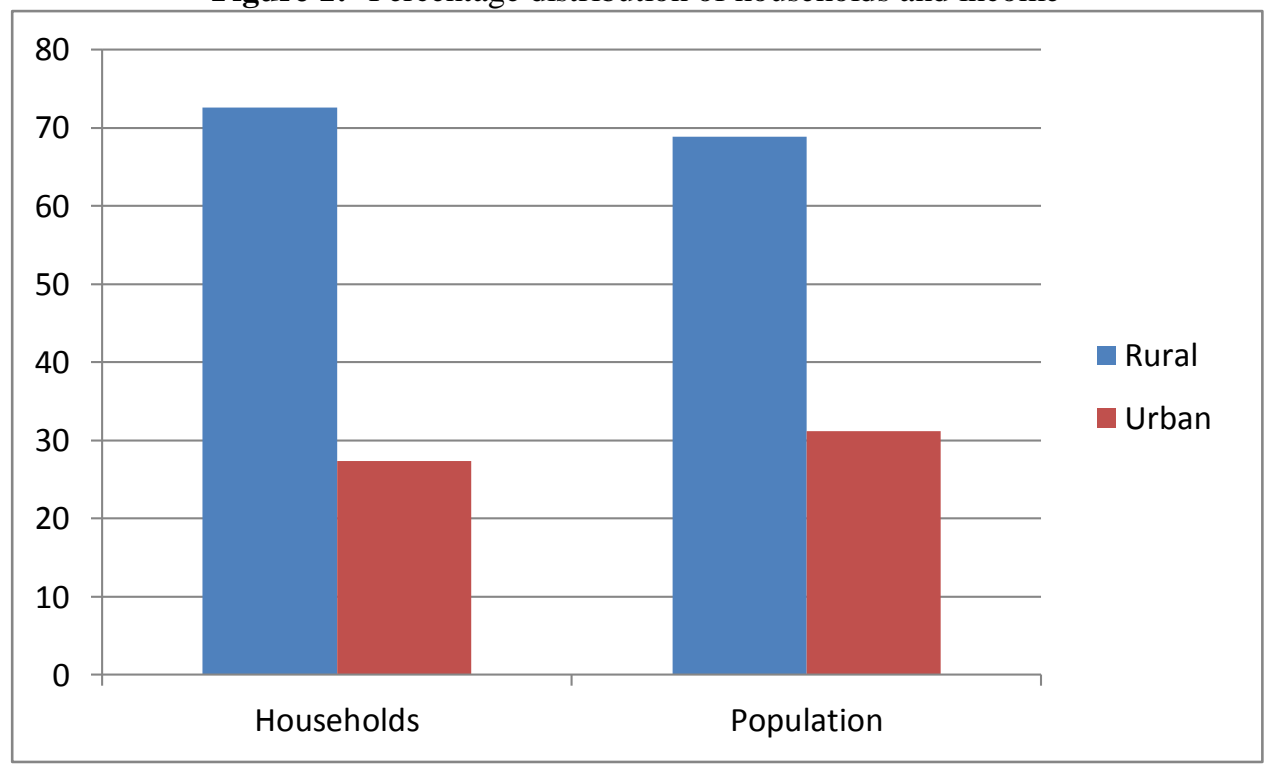

Source: data from Census of India; 2011 


\section{Rising Rural Prosperity:-}

India is now seeing a dramatic shift towards prosperity in rural households. To drive home the potential of rural India just consider some of these impressive facts about the rural sector. As per the National Council for Applied Economic Research (NCAER) study, there are as many 'middle income and above' households in the rural areas as there are in the urban areas. There are almost twice as many 'lower middle income' households in rural areas as in the urban areas.

Figure 2:-Distribution of people income-wise

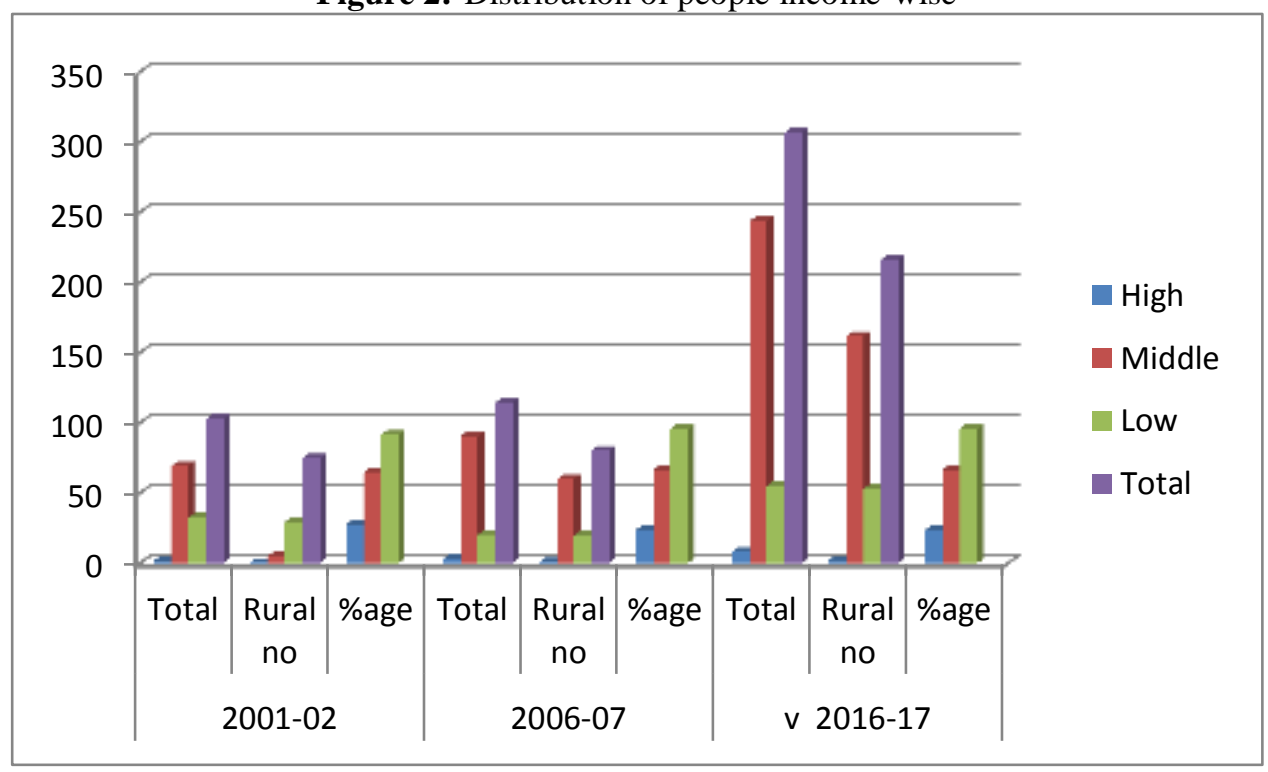

Source: data from NCAER reports 2001-02, 2006-07.

* NCAER reports income prices at 2006-07, to bring these to current prices (2016-17) income level a conversion factor of 2.7 has been taken to adjust the nominal per capita income growth.

According to NCAER projections, by 2006 - 07, the lowest income class (i.e.Rs.2500 and below) will shrink by more than $60 \%$. The higher income classes are likely to double by $2006-07$. This apparently is the result of development work, which happened under the five years plans and other special programs such as land reforms, rural electrification rural communication, and rural credit facilities, etc. The absolute size of the rural market is thus expected to double that of urban India. But despite the high rural share in these categories, the rural penetration rates are low, thus offering tremendous potential for growth. According to Mr.D.Shivakumar, Business Head (Hair), Personal Products Division, Hindustan Lever Limited, the money available to spend on FMCG (Fast Moving Consumer Goods) products by urban India is Rs.49,500 crores as against is Rs.63,500 crores in rural India.

\section{What exactly is meant by the rural sector?}

The term "rural sector" is confusing because not all government bodies use the same definition. Several distinct definitions (which are relevant for the insurance sector) have been used in the past.

The Reserve Bank of India (RBI) defines four different entities. All definitions apply to the population size. The only relevant factor is the number of people living in a well-defined geographical boundary. Thus, the density of the population or the activity of the population is of no relevance for the definition of the RBI. The entities defined by the RBI are as follows:

(1) A given geographical area is called rural if it has less than 10,000 people.

(2) A given geographical area is called semi-urban if it has more than 10,000 but less than 100,000 people. (3) A given geographical area is called urban if it has more than 100,000 but less than 1,000,000 people. (4) A given geographical area is called metropolitan if it has more than 1,000,000 people.

- The Census of India recognizes two areas: urban and rural. The only category it explicitly defines, however, is urban. Thus, the definition of a rural area is by default whatever is not covered by the definition of an urban area. 
The census of 1991 defined an urban area as an area that has all of the following three characteristics: (1) a minimum population of 5,000 ; (2) at least $75 \%$ of the male workers engaged in non-agricultural pursuits; and (3) a population density of at least 400 persons per square kilometer.

- Under the "Obligations of Insurers to Rural Social Sectors" of the Insurance Regulatory and Development Authority Act, 1999, the IRDA defines the rural sector as follows. "Rural sector" shall mean any place as per the latest census which has: (i) a population of not more than 5,000; (ii) a density of population of not more than 400 per square kilometer; and (iii) at least $75 \%$ of the male main working population is engaged in agriculture.

\section{Present Scenario of Rural Insurance:-}

The penetration of life insurance in India compared to international standards especially the penetration in rural areas was poor and that has been one of the prime reason behind the reforms in this sector. The poor performance of Indian life insurance industry was mentioned by the Malhotra Committee in its report and advocated for the participation of private domestic and foreign insurers in the Indian insurance industry and the insurance regulator IRDA has recommended some mandatory obligations for all insurers in the life insurance industry. All insurers are obligatory to provide some coverage for the rural and social sectoras stipulated in the IRDA Regulations, 2002, which is known as the "Obligations of Insurers toRural or Social Sectors". Life insurers have to maintain the following mandatory coverage in the rural areas for the first five years as,

(a) five per cent in the first financial year;

(b) seven per cent in the second financial year;

(c) ten per cent in the third financial year;

(d) twelve per cent in the fourth financial year; and

(e) fifteen per cent in the fifth year of total policies written direct in that year.

IRDA issued new guidelines for the insurers in respect of rural and social sector obligations. As per new amendments in 2007-08, the obligation for the private life insurers' up to 10th year of operations have been laid down along with the revised performance yard stick for the public sector unit LIC of India. The obligations of the private life insurers according to the new amendment (IRDA/Reg/1/42/2008)8 are as follows:

\section{In respect of rural sector:-}

(1) eighteen per cent (18\%) in the seventh financial year,

(2) nineteen per cent (19\%) in the eighth and ninth financial year, and

(3) twenty per cent $(20 \%)$ in the tenth financial year, of the total policies written direct in that year.

The obligations of all insurers towards the rural sector for the tenth financial year shall also be applicable in respect of financial years there after. Based on the amendments notified by the IRDA (03/01/2008), the obligation of LIC of India in respect of rural sector for the financial year 2007-08, 2008-09 and 2009-10 are as under; Rural sector obligations

(1) twenty four per cent of the total policies written direct in 2007-08,

(2) twenty five per cent of the total policies written direct in 2008-09 and in 2009-10.

Before going into the post reform performances of the life insurance industry in penetrating India, it would be necessary to see the development made by the state owned life insurer, LIC of India in the pre reform period. LIC had done a splendid job in spreading the life insurance in the rural areas. LIC of India's share of policies in the total new business in the rural sector rose to $57.5 \%$ in 1999-2000 from $44.7 \%$ in 1991-92. At the end of the financial year 1999-2000, LIC has underwritten almost $50 \%$ of its total sum assured business from the rural sector.

The life insurers underwrote 68.99 lakh policies in the rural sector, viz., 25.8 percent of the new individual policies (267.08 lakh policies) underwritten by them in $\mathbf{2 0 1 5 - 1 6}$. LIC underwrote 25.70 per cent of the new policies and private insurers underwrote 26.3 per cent of their new individual policies in the rural sector. Though the share of total number of policies sold in rural areas is higher than that of the urban areas, the share in total business volume is low in the same area, which means that the premium volume is less in the rural India. After the opening up of the insurance sector, IRDA issued new definition for the rural sector in the year 2000 to identify the rural areas of India for the life insurers as per the new census. The formal definition of the rural sector is the one, which is not urban. 
Urban sector is defined to include all locations with municipality, corporation, notified town area and all other locations specifying the criteria,

(1) A minimum population of five thousand,

(2) At least $75 \%$ of male workforce are engaged in non-agricultural activities, and

(3) A population density of over 400 people per sq. $\mathrm{km}$.

On the basis of new definition of the rural, LIC 's new business in terms of policies in the rural are revised at around $18 \%$ in 1999-00 which was $57 \%$ according to the old yardstick. At the end of financial year 2007-08, LIC has written $21.67 \%$ of its new policies from the rural sector. Growth rate in the rural and social sector is increasing as a result of the IRDA's focus on this sector. India's life insurers have exceeded expectations in terms of growing their business in rural India, and most firms in the business are actually ahead of targets laid down by Insurance Regulatory and Development Authority. An analysis of data of seven life insurance companies for 2015-16 which accounted for more than $80 \%$ of the life insurance market, reveals that all of them achieved their individual targets laid down by IRDA (see Table: 3). The seven insurers are Aviva Life Insurance Co. India Ltd, Birla Sun Life Insurance Co. Ltd, ICICI Prudential Life Insurance Co. Ltd, Life Insurance Corporation of India (LIC), Max New York Life Insurance Co. Ltd. Reliance Life Insurance Co. Ltd and SBI Life Insurance Co. Ltd.

Figure 3:-Target Vs achievement

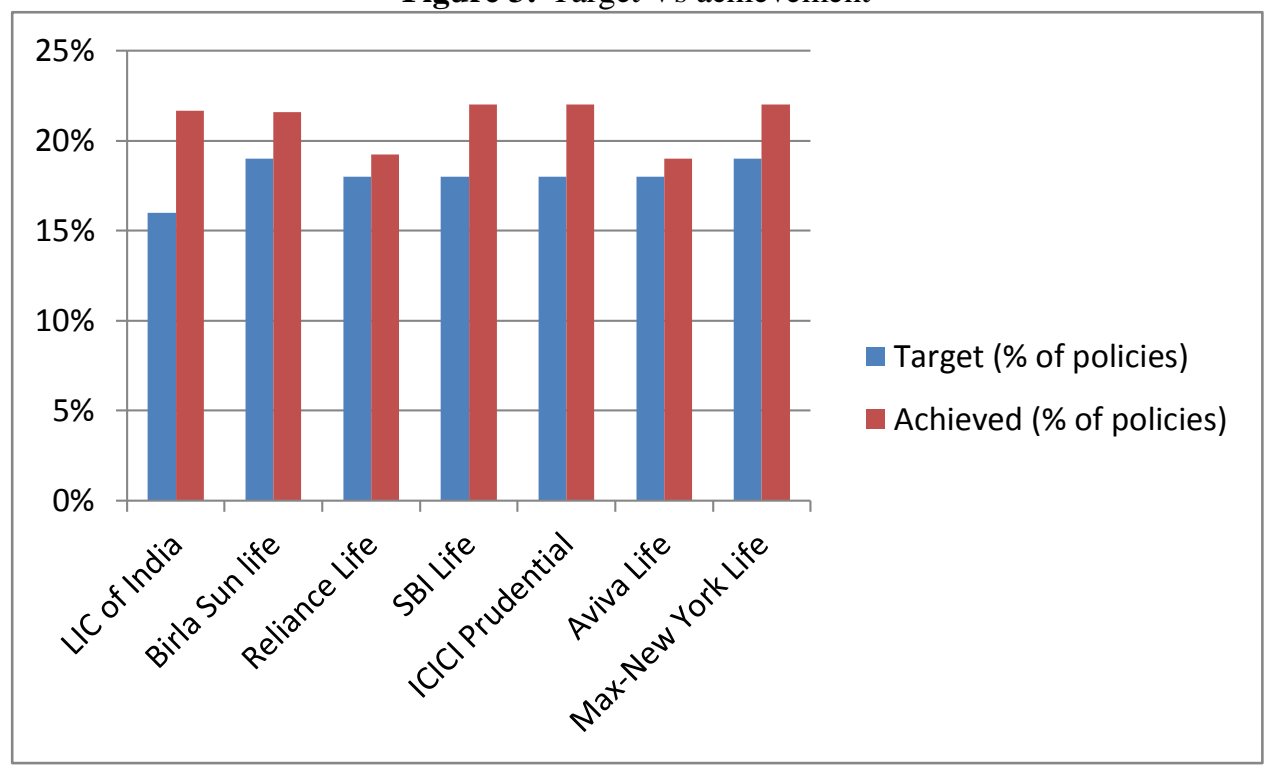

Source: data from IRDA Annual Report; 2007-08

During financial year 2015-16, all the twenty three private sector life insurance companies had fulfilled their rural sector obligations. The number of policies underwritten by them in the rural sector as a percentage of the total policies underwritten in the year 2015-16 was as per the obligations applicable to them.

In spite of this development the rural life insurance penetration is still below any standard. According to a report, 'Insurance in Next 2 Years', by ASSOCHAM, (www.assocham.org), May 2008, out of 78\% households having awareness about life insurance in rural India, only $24 \%$ were policy owners. Rural India may offer a business opportunity worth US\$ 23 billion for the insurers if the segment can be wooed with innovative schemes at affordable premiums.

\section{Efforts Made By The Life Insurers:-}

In penetrating rural market, the efforts made by the life insurers are encouraging in the present scenario. In the post reform period the growth in the number of life insurance agents is much faster than ever before in India. In the first year of reform (2000-2001) the total numbers of life insurance agents working in the life insurance industry were 1, 15,715 which consisting 66,777 and 48,938 life agents from urban and rural sector respectively. 
Figure 4:-Number of Agents of Life Insurers

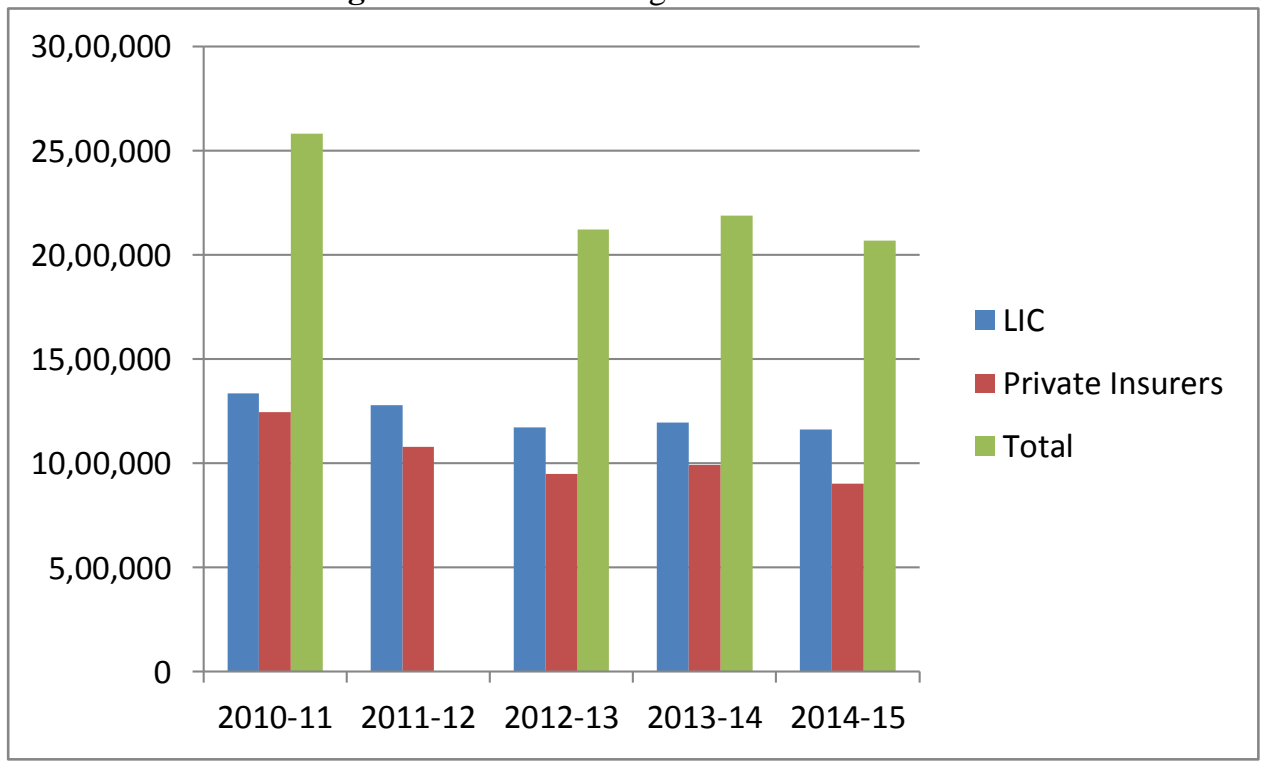

Source: data from Handbook of Indian Insurance Statistics 2014-15

As evident from the table above, it is clear that LIC could focus well to penetrate the insurance market especially rural market while private insurers did not focus passionately to tap this important segment. Most of the rural people neither believe in private insurers nor want to be recruited as agents of private life insurance companies.

Figure5:-Number of Rural Branches of Life Insurers

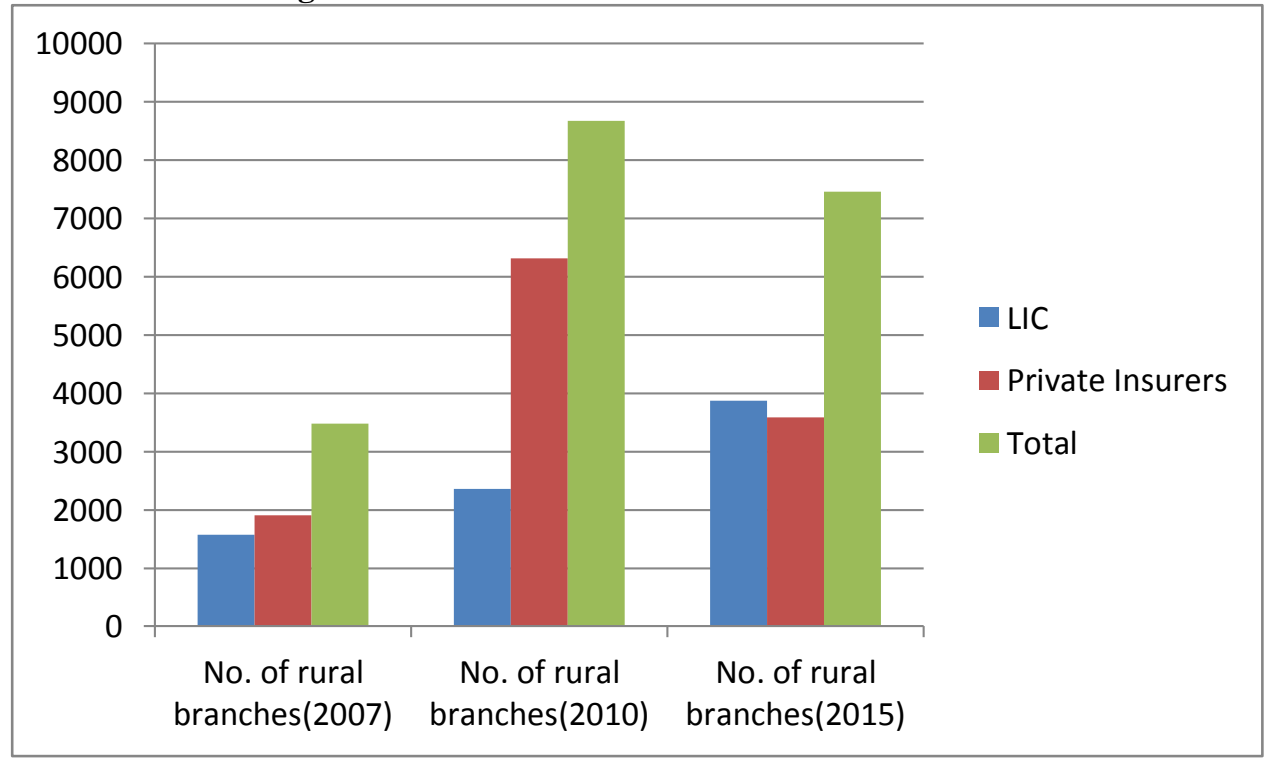

Source: data from Handbook of Indian Insurance Statistics 2014-15.

To tap the potential customers, insurers also expanded their rural branches through out the country. Total number of life insurance rural branches of all the life insurance companies in India (private \& state) goes up to 8669 at the end of $31^{\text {st }}$ March 2010 from 3477 in 31st March 2007 but after this it reduced to 7461 in year 2015. This happened because private life insurers closed their branches. Total branch offices of private life insurance companies were 6,316 in the year 2010 which reduced to 3584 in the year 2015. The state life insurer i.e. Life Insurance Corporation of India increased their rural branch offices from 1569 in the year 2007 to 2353 in the year 2010 and then to 3877 in 
the year 2015. In fact, to tap the huge untapped rural Indian life insurance market LIC left private life insurance companies behind in the financial year 2014-15 in respect of number of branches operating in the rural life insurance market.

\section{Challenges In Rural Life Insurance Sector:-}

The three inherent challenges in addressing the needs for rural life insurance are the product design, distribution and after sales service of those customized insurance products effectively to reach the benefit of such products to the needy. Therefore, there is a need to introduce more and more customized life insurance (individual and group) products for the lower income strata as well as a major part of rural market is being constituted by these people only. With the advent of such new customized insurance products, poor people will entice to have such benefits for future eventualities. The introduction of such products does not end the obstacles for the development of the life insurance in rural India. The very next problem is the marketing and distribution of such products. Rural India is a huge as the targeted consumers live sparsely. To serve this huge clientele, we also need alternate set of distribution channels besides agency channel to reach them and with the present state of penetration of insurers in the rural areas are not enough to achieve such a colossal task. Though the branch expansion of the insurers has improved in the post insurance reform period it is still not enough to penetrate every corner of the rural parts of country. In 2008 out of total branches of all life insurers operating in India, only $32 \%$ was from rural areas. The very next and crucial problem is to provide services to the existing policyholders. Renewal collection is a big problem as in case of low premium policies, agents don't focus on the collection as their commission is meager. Renewal collection is badly affected in case of private life insurers as they don't have good retention of their field force i.e. sales managers and agents. In case of micro insurance products, the main factors behind showing less interest by the Insurers are especially for rural market is high cost of servicing the product and the difficulty in distribution of micro-insurance products. In India, it is often considered that a micro insurance policy is simply a low-premium insurance policy. But actually, there are a number of other important factors which governs the micro insurance policies.

(i) The low-income clients often live in remote rural areas and to serve this clientele, insurers require a different set of distribution channels and new approaches to marketing and contracting micro insurance products.

(ii) It is often found that the low-income clients are unfamiliar with the concept of insurance, especially microinsurance, requiring a different set of new approaches to contracting to insurance products.

(iii) There also exist challenges in product design. Due to the lack of a historical database on claims, compels the insurers to calculate premiums based on imprecisely macro aggregates which eventually affect the pricing of the product as the insurance companies become overcautious on margins.

(iv) It is also found that there are very little choices available before the consumers to choose from. Indian micro insurance market is yet to offer array of customized products to suit the needs of the poor.

(v) It is found that the 'Minimum Amount of Cover' requirement in the micro-insurance products is bit high which prohibit a large segment of the poor from acquiring benefit out of the micro-insurance products.

According to the study of CGAP Working Groups on Micro-insurance, 2005, there have some unverified report that few private life insurers are dumping poorly serviced micro- insurance products to meet the quota requirements and some are stop selling insurance products (including micro insurance products) once they meet their target (Rural or Social Sectors) which was specified by the regulator, IRDA.

\section{Conclusion and Recommendations:-}

Life insurers in rural market have not done well and much more efforts are required to tap the untapped rural market. Indian rural market has tremendous potential. It is evident that the state insurer Life Insurance Corporation of India has better hold of the Indian rural market and private insurers have to do a lot to earn trust of rural people. During last few years, Private Life Insurance Companies like Reliance, Bajaj and other's have closed their branches especially from the rural areas which has gone against private insurers and hence it is advisable that they should open their branches in rural market only after doing a good research. Payback period in case of rural branches is longer and hence they must have patience otherwise the common rural folk have an established concept about Private companies that they will close down soon "BHAAGJAIGEE" i.e. "private company runs away" will never change. Moreover the market is still not properly tapped. Insurers should come out of shell and should endeavor for tapping $100 \%$ potential of the market. Following distribution channels will help besides the conventional agency channel, (where distribution is being done by sales managers/ development officers and individual agents). 
Franchisee, Corporate Agent: Franchisee or business associates, corporate agents can be appointed by companies who in turn can recruit agents. A Gram Panchayat, Local Organization, AanganBaadi, Non Government Organization, Local hospitals, Self Help Groupscan be effective business associates as rural people are in constant touch of these organizations. They can use concept of networking for quick coverage of market as rural people like the concept of networking because they see earning potential as well. Broker: As they can sell product of more than one or of all insurers, people will get more choice and hence they would like this channel. Bank Assurance; Rural Development Banks, Banks: As people see banks as trustworthy so insurer's partnership with banks in selling life insurance will be beneficial for all. As they believe that just because of selling insurance, banks will not close down their branches. Post Office: Rural population is scarcely distributed and hence it is time taking and costly to reach all the potential people. As post office has a very good network in rural India and hence it will be very beneficial for both the post office and insurers to start selling products also through post offices. Stall at village fair can be effective as rural people go there with buying mood and normally with family and hence they can be contacted for insuring them even if they don't buy there a good prospecting list can be prepared and such people can be canvassed later on to buy the insurance. Insurance mobile van, this is a very good concept, a van well dressed with flex boards of life insurance products can be used, it should have sound system so that pre-recorded company ads can be played. This will move from one village to another. There should be some official from insurance company with proposal forms and product brochures that can be filled that time only.

\section{References:-}

1. Annual Reports of IRDA, (2007-2008), (2006-2007), (2004-2005), (2000-2001) \& (1999-2000) IRDA, Hyderabad, India, (www.irdaindia.gov.in).

2. Annual Reports of LICI, Various Years, Life Insurance Corporation of India, Mumbai; (www.liciindia.com); Economic and Political Weekly, (2001), January 20.

3. Bhave, S. R. (1970), “Saga of Security: Story of Indian Life Insurance (1870-1970)”, LIC of India, Bombay, India, p. 20.

4. Desai, G. R. (1973), “Life Insurance in India: Its History and Dimensions of Growth”, Macmillan Press, New Delhi, pp. 70-74.

5. Garand (2005), "Vimo SEWA, India," Good and Bad Practices in Micro insurance, Case Study No.16, International Labour Organization, Geneva.

6. http://www.equitymaster.com/ Rural Life Insurance in Post Reform Era in India: Growth and Opportunities 257.

7. Handbook of Indian Insurance Statistics 2014-15.

8. IRDA (Obligation of Insurance to Rural and Social Sector) Regulation, IRDA Notification: (F. No. IRDA/Reg/1/42/2008), IRDA, Hyderabad, India (www.irdaindia.gov.in).

9. IRDA (Obligation of Insurance to Rural and Social Sector) Regulation, IRDA Notification: (F. No. IRDA/Reg/2/43/2008), January, 25, 2008, IRDA, Hyderabad, India. (www.irdaindia.gov.in).

10. IRDA (Obligation of Insurance to Rural and Social Sector) Regulation, 2000, 2002, IRDA, Hyderabad, India. (www.irdaindia.gov.in).

11. IRDA Act' 1999, (www.irda.gov.in).

12. IRDA (Micro-Insurance) Regulations (2005), the Gazette of India: Extraordinary (Part-III, Sec. 4), IRDA Notification, Hyderabad, 10th November, 2005.

13. Kumar, D. (Ed), (1991), “Tryst with Trust: The LIC Story”, LIC of India, Bombay, India, pp. 4-13.

14. Mitra, D and A, Ghosh, (2007), "Private Life Insurance Consumption in Rural India and Role of Post Offices-An Analysis", The Asian Economic Review, Vol. 49, No. 1, pp. 39-45.

15. Press Information Bureau (PIB), (GoI), Thursday, 30th August, 2007, New Delhi; The Economic Times, Monday, 4th August, 2008.

16. PIB, (GoI), Wednesday, 11th February, 2009, Ministry of Communication and Information Technology, New Delhi.

17. Ranade, A and R, Ahuja (1999), "Life Insurance in India: Emerging Issues", Economic and Political Weekly, January (16-23), pp. 203-211.

18. Roth, J., C. Churchill, G. Ramm and Nametra (2005), "Micro Insurance and Microfinance Institutions: Evidence from India", Case Study No. 15, CGAP Working Group on Micro Insurance, SDA-DFIDGTZ \& ILO. (www.irdaindia.gov.in).

19. Sinha, T. (2004), “The Indian Insurance Industry: Challenges and Prospects”, Swiss Re Visiting Professor, Institute of Insurance and Risk Management, Hyderabad, India.

20. The Economic Times, Monday, 2nd June, 2008.

21. UNDP, (2007), "Building Security for the Poor-Potential and Prospects for Micro Insurance in India," UNDP Regional Centre, Colombo, Sri Lanka.

22. (www.nabard.org/pdf/report_financial/chap_XI/pdf). 